Research Article

\title{
The Effect of Anger, Gratitude and Psychological Well-Being as Determinants of Forgiveness in Adults
}

\author{
Seda Donat Bacıŏglü ${ }^{10}$ \\ Trakya University
}

${ }^{1}$ Asst. Prof. Dr., Department of Guidance and Counseling, Trakya University Education Faculty, Edirne, Turkey. E-mail: sedadonatbacioglu@trakya.edu.tr

Corresponding author:

Seda Donat Bacıoğlu

E-mail:

sedadonatbacioglu@trakya.edu.tr

eISSN: 2458-9675

Received: 26.05.2020

Revision: 04.10 .2020

Accepted: 13.10 .2020

(C) Copyright 2020

by Author(s)

\begin{abstract}
The purpose of this study is to examine the contribution of anger, gratitude and psychological well-being in predicting forgiveness. The study group consists of 221 adult (62\% female and $38 \%$ male). Anger-Anger Style Scale, Gratitude Scale, Psychological Well-Being Scale and Heartland Forgiveness Scale were used as data collection tools. In analyzing the data obtained, Pearson moments correlation analysis and regression analysis were used. Research findings showed that there was a negative relationship between trait anger, anger-in sub-dimensions and forgiveness; there were positive relationships between the anger control sub-dimension, gratitude, psychological wellbeing and forgiveness. It has been determined that the common effects of these variables explain $42 \%$ of the variance of adults for forgiveness. In the light of the findings obtained from the research, suggestions for future research are presented.
\end{abstract}

Keywords:

Adult, Anger, Gratitude, Psychological Well-Being, Forgiveness

\section{Yetişkinlerịn Affediciliğinin Belirleyicisi Olarak Öfke, Şükran ve Psikolojik İyi Oluşun Etkisi}

Öz

$\mathrm{Bu}$ araştırmanın amacı, öfke, şükran, psikolojik iyi oluş değişkenlerinin yetişkinlerin affetme düzeyini ne derece yordadığını incelemektir. Araştırmanın çalışma grubunu, 138’i (\% 62) kadın ve 83’ui (\% 38) erkek olmak üzere toplam 221 yetişkin oluşturmuştur. Veri toplama araçları olarak Öfke-Öfke Tarz Ölçeği, Şükran Ölçeği, Psikolojik İyi Oluş Ölçeği ve Heartland Affetme Ölçeği kullanılmıştır. Elde edilen verilerin analizinde, Pearson momentler çarpımı korelasyonu analizi ve çoklu regresyon analizi kullanılmıştır. Araştırma bulguları, sürekli öfke ve öfke-içte alt boyutları ile affetme arasında negatif yönlü anlamlı ilişkiler; öfke kontrolü alt boyutu, şükran ve psikolojik iyi oluş ile affetme arasında pozitif yönlü anlamlı ilişkiler olduğunu göstermektedir. Söz konusu değişkenlerin ortak etkilerinin yetişkinlerin affetme düzeylerine ilişkin varyansının \% 42'sini açıkladığı tespit edilmiştir. Araştırmadan elde edilen bulgular ışığında ileride yapılacak araştırmalar için öneriler sunulmuştur.

Anahtar Kelimeler:

Yetişkin, Öfke, Şükran, Psikolojik İyi Oluş, Affetme 
Forgiveness is the act of curing and strengthening oneself by reconciliation with past. If we want to progress in this life feeling free, relieved and undaunted, forgiveness comes up as an option not an obligation (Sharma \& Das, 2017). Reviewed in other disciplines, forgiveness is defined in psychology as "a deliberative decision to abandon one's right to resentment, negative judgment and indifferent behavior toward one or group who unjustly hurt you" (Coyle \& Enright, 1998). On the other hand, it is also entitled as cognitive, emotional and behavioral change of a person who experiences forgiveness as a process in an altruist aspect (McCullough \& Witvlient, 2005). In short, forgiveness is defined as "a process of abandon the resentment and getting well" (Yildiz, 2017). In this process, negative emotions and thoughts towards others and oneself are gradually lessened (Safaria, 2014). Unforgiveness is a negative emotional state that a person feels hostility, resentment, anger and hate towards another who annoys him/her (Sharma \& Das, 2017). Boleyn-Fitzgerald (2002) reported that forgiveness is "undisputedly the most important virtue to control anger". Every individual experiences a sense of anger when they encounter situations that they are victims, hurt, blocked or under threat and oppression. Especially, one of the emotions experienced intensely during periods of conflict and resentment is anger (Nussbaum, 2016); because in such cases, the underlying emotions are primary emotions that cause anger, such as not being understood or injury (Hendricks, et al., 2013). Anger and primary emotions that produce anger arise and reinforce the belief that the situation is not as it should be. Therefore, very angry people are expected to have more difficulty in forgiveness. On the other hand, it can be said that as long as the anger and the underlying primary emotions decrease, it will be easier for individuals to forgive (Malakçığlu, 2018). Some studies showed that forgiveness reduces emotions such as resentment, anger, hostility, anxiety, but increases emotions such as love, happiness, hope, compassion and mercy (Enright \& Fitzgibbons, 2015; Wade et al., 2014). If individuals can transform negative emotions and forgive, they contribute to their subjective well-being and therefore, they can take precautions against psychological disorders that may occur.

Gratitude is the attitude of accepting what a person takes from life and being grateful to life (Watkins et al., 2003). It is an action that adds beauty to life by appreciating simple events in life. It strengthens social relations, increases psychological wellbeing, improves optimistic behavior and strengthens the sense of commitment due to being a positive emotion (Fredrickson, 2004). According to Lyubomirsky (2008), gratitude is wondering, appreciating, seeing the beautiful side of negativity, recognizing abundance and richness and getting deep into them, thanking God or someone in our lives, being aware of and expressing the beauties (felicities) we have. Having the feeling of gratitude is an antidote to negative emotions for individuals and is an emotion that neutralizes negativity in such as jealousy, envy, ambition, hostility, anxiety and anger (Kardaş \& Yalçın, 2018). Gratitude and forgiveness are 
conceptually associated with psychological and physical health (Breen et al., 2010). Researches showed that as the level of gratitude increases, anger, loneliness and depressive symptoms decrease (Breen et al., 2010; Wu et al., 2018).

Psychological well-being requires competencies as self-acceptance in all aspects, the ability to establish positive relationships with others, purpose and meaning in life, being open to personal growth, autonomy/independence and environmental mastery (Ryff, 1989). Psychological well-being also expresses positive features such as nourishing of spiritual need, autonomy, independence, forgiveness, establishing close relationships with people and productivity (Güleç, 2016). Researches showed that individuals with high forgiveness also have high psychological well-being (Koç et al., 2016; Ma, Chen \& Guo, 2019; Uysal \& Sat1c1, 2014). While unforgiveness is seen as an essential component of stress (Worthington \& Scherer 2004); forgiveness can be a way to cope with interpersonal stress in a way that promotes positive harmony (Toussaint \& Webb, 2005). Worthington, Witvliet, Lerner and Scherer (2005) have suggested that forgiveness can provide more well-being by alleviating the effects of stress and negative emotions and supporting a more harmonious response for the individual. Toussaint and Webb (2005) reviewed 18 studies examining the effects of forgiveness on mental health. In general, their findings showed that when it comes to forgiveness, anxiety, depression and anger have decreased. Krause and Ellison (2003) reported that there was a relationship between forgiving others and psychological well-being, especially older people who forgave others showed less depressive symptoms, less death anxiety and more life satisfaction.

As it can be seen from the studies, it is possible to say that forgiveness alone is a significant predictor of the relationship between anger, gratitude and psychological well-being variables, the decrease in the feeling of trait anger and the increase in the sense of gratitude and the psychological health (Topbaşoğlu-Altan \& Çivitçi, 2017; Uysal \& Akın, 2014; Zümbül, 2019). The purpose of this study is to examine the effects of anger, gratitude and psychological well-being on forgiveness, which are the variables whose relationships have not been considered together. With an uncontrollable destructive anger, it is very difficult to develop and settle positive emotions for the individual. On the other hand, emotions that affect an individual's well-being such as love, affection, and mercy are realized through forgiveness (Thompson et al., 2005). Unlike previous research, this research is considered important in terms of being grateful, well-being and controlling anger help to develop forgiveness. The findings obtained from the research are expected to contribute to the studies aimed at increasing the level of forgiveness of adult individuals and in the guidance and psychological counseling services offered to individuals. Besides, it is predicted that this research will help adult individuals to have the capacity to create healthier and satisfying interactions with a positive feeling, gratitude in a high 
level of forgiveness by becoming individuals who can manage their anger in their relationships with themselves, their families and in business life. In line with these purposes, the following questions were sought in the research:

1. Is there a relationship between forgiveness, anger, gratitude and psychological well-being scores of adults?

2. What is the effect of anger, gratitude and psychological well-being scores to predict forgiveness scores?

\section{Method}

Aiming to examine the variables of anger, gratitude and psychological wellbeing, which are thought to be the predictors of forgiveness in adults, this study is a descriptive research based on a relational screening model.

\section{Participants}

The study group of the study consists of prospective teachers who got pedagogical formation training in Trakya University Faculty of Education in the 2017-2018 academic year. A total of 221 adult volunteers participated in the study, selected according to the appropriate sampling method. 166 of the participants $(75 \%)$ were aged 24 and under, 55 (25\%) were in the age range of 25 and above, 138 (62\%) were female and $83(38 \%)$ were male adults.

\section{Data Collection Tools}

The State - Trait Anger Scale: The original version of the scale was developed by Spielberger (1983), and it was adapted into Turkish by Özer (1994). The scale has thirtyfour items; the first 10 items measure the level of trait anger, 24 items determine the anger styles (anger-in, anger-out and anger-control sub-dimensions) of individuals. Total score cannot be obtained from the scale, scoring can be done according to the sub-dimensions. High scores obtained from the trait anger indicate that anger level is high; high scores obtained from the anger-in-scale indicate that anger is suppressed, held inside; high scores from the anger-out scale indicate that anger is easily expressed, and high scores from the anger-control scale indicate that anger can be controlled. Cronbach's alpha coefficients of the scale were found as 0.79 for the 'trait anger' dimension, 0.78 for the 'anger-out expression' dimension, 0.62 for the 'anger-in expression' dimension, and 0.84 for the 'anger control' dimension. Cronbach's alpha coefficients of scale for this research were found as 0.76 for 'trait anger' dimension, 0.79 for 'anger-out expression' dimension, 0.65 for 'anger-in expression' dimension and lastly 0.79 for 'anger control' dimension. The reliability coefficient of the scale in this study was calculated as .85 for trait anger dimension, .81 for anger-out expression, and .63 for anger-in expression. 
Gratitude Scale: This 25-item scale was developed by Kardaş and Yalçın (2019). There are six sub-dimensions of the scale: Positive Social Comparison, Focusing on Positive, Appreciating contributions of Family and Others, Feelings of Abundance instead of Deprivation, Gratitude for Simple Things and Expressing Gratitude. As a result of confirmatory factor analysis, the fit values of the scale were found as $\chi^{2}$ / Sd 2.30; RMSEA 0.061, CFI 0.95, NFI 0.92, IFI 0.95, NNFI 0.94 and GFI 0. The internal consistency coefficient of total score of the scale was calculated as 0.88 . The reliability coefficient of the scale in this study was calculated as .90 .

Psychological Well-Being Scale: It was developed by Diener et al. (2010) in a shorter and more holistic way for the existing psychological well-being measurements. It was adapted into Turkish by Telef (2013). Cronbach's alpha internal consistency coefficient obtained in the reliability study of the scale was calculated as .80 . As a result of the confirmatory factor analysis, when the fit indices were analyzed, it was observed that the ratio of chi-square value to degree of freedom $(92.90 / 20=$ 4.645) was below 5. Other fit indices were found as RMSEA $=0.08, \mathrm{SRMR}=0.04$, $\mathrm{GFI}=0.96, \mathrm{NFI}=0.94, \mathrm{RFI}=0.92, \mathrm{CFI}=0.95$ ve $\mathrm{IFI}=0.95$. The items of the scale are scored 1 to 7 and the scores that can be obtained vary between 8 and 56. A high score indicates that the person has many psychological resources and strengths. The reliability coefficient of the scale was found as .86 for the sample group of this study. In this study, the reliability coefficient of the scale was calculated as .78.

Heartland Forgiveness Scale: The scale was developed by Thompson et al. (2005) to determine the level of forgiveness of the individual with 18 -item. Its adaptation to Turkish culture were carried out by Bugay (2010). The scale has three subdimensions: forgiveness of self, forgiveness of others and forgiveness of situation.

A high score obtained from every sub-dimension and total score in the 7-point Likert-type (1-always wrong, 7-always correct) scale states that the level of forgiveness of the individual is high. In the Turkish version, Cronbach's alpha reliability coefficient overall was 0.81 , for forgiveness of self-subscale 0.64 , for forgiveness of others 0.79 , and for forgiveness of situation 0.76 . The reliability coefficient of the scale in this study was calculated as .82 .

\section{Data Analysis}

The data were analyzed using SPSS 21 program. Since the skewness and kurtosis values of the scale are between -3 and +3 , normality has been provided and parametric test techniques have been used in the analysis. In the analysis of data obtained from the research, Pearson Moments Product Correlation Coefficient was calculated to examine the relationship between anger, gratitude, psychological well-being and forgiveness. Multiple regression test was conducted to examine the contribution of independent variables (anger, gratitude and psychological well-being) in predicting forgiveness. 


\section{Findings}

In this section, the sub dimensions of anger such as trait anger, anger-in, anger-out, anger control, gratitude and psychological well-being are regarded as independent variables, and forgiveness is a dependent variable. Descriptive statistics of arithmetic mean, standard deviation, skewness and kurtosis values related to the dependent and independent variables of the research were shown in Table 1.

Table 1.

Descriptive Statistics Related to Variables

\begin{tabular}{lccccccc}
\hline Variables & $\mathrm{n}$ & Minimum & Maximum & Mean & ss & Skewness & Kurtosis \\
\hline Trait Anger & 221 & 10.00 & 40.00 & 21.72 & 5.94 & .629 & -.143 \\
Anger-In & 221 & 8.00 & 30.00 & 16.54 & 3.71 & .613 & .773 \\
Anger-Out & 221 & 8.00 & 32.00 & 16.57 & 4.44 & .700 & .674 \\
Anger Control & 221 & 11.00 & 32.00 & 22.09 & 4.56 & .088 & -.266 \\
Gratitude & 221 & 46.00 & 125.00 & 97.42 & 13.12 & -.777 & 1.322 \\
Forgiveness & 221 & 36.00 & 126.00 & 81.37 & 16.12 & .104 & -.062 \\
Psychological well-being & 221 & 20.00 & 56.00 & 44.20 & 6.20 & -.871 & 1.259 \\
\hline
\end{tabular}

The relationship between anger, gratitude, psychological well-being and forgiveness variables were examined with Pearson Moments Product Correlation Coefficient. The obtained data were shown in Table 2.

Table 2.

Correlation Related to the Relations between Dependent and Independent Variables

\begin{tabular}{lccccccc}
\hline & 1 & 2 & 3 & 4 & 5 & 6 & 7 \\
\hline Trait Anger & 1 & $.491^{* *}$ & $.747^{* *}$ & $-.449^{* *}$ & $-.151^{*}$ & $-.517^{* *}$ & $-.299^{* *}$ \\
\hline Anger-In & & 1 & $.433^{* *}$ & -.033 & $-.187^{* *}$ & $-.369^{* *}$ & $-.245^{* *}$ \\
\hline Anger-Out & & & 1 & $-.440^{* *}$ & -.091 & $-.443^{* *}$ & $-.149^{*}$ \\
\hline Anger Control & & & & 1 & $.138^{*}$ & $.429^{* *}$ & $.252^{* *}$ \\
\hline Gratitude & & & & & & \\
\hline
\end{tabular}

Forgiveness

Psychological well-being

According to Table 2, there was a weak negative relationship between trait anger and gratitude $(r=-.151 ; p<0.05)$; a moderate negative relationship between forgiveness $(r=-.517 ; p<0.01)$ and a weak negative relationship $(r=-.299 ; p<0.01)$ between psychological well-being. There was a weak negative relationship between anger-in and gratitude $(r=-.187 ; p<0.01)$; a moderate negative relationship between forgiveness $(r=-.369 ; p<0.01)$ and a weak negative relationship between psychological well-being $(r=-.245 ; p<0.01)$. There was a moderate negative relationship between anger-out and forgiveness $(r=-.443 ; p<0.01)$; a weak negative relationship between 
psychological well-being $(r=-.149 ; p<0.05)$. It was also found that there was a weak positive relationship between anger control and gratitude $(r=.138 ; p<0.05)$; a moderate positive relationship between forgiveness $(r=.429 ; p<0.01)$; a weak positive relationship between psychological well-being $(r=.252 ; p<0.01)$. It was seen that there were moderate positive relationships between gratitude and forgiveness and between psychological well-being $(r=.329 ; r=.504)$. There was a moderate positive relationship between forgiveness and psychological well-being $(r=.429 ; p<0.01)$.

The findings obtained from the regression test showing the level of predicting forgiveness of the independent variables anger, gratitude and psychological wellbeing were shown in Table 3.

Table 3.

Results of Regression Analysis Related to the Power of Anger, Gratitude and Psychological Well-Being Variables to Predict

\begin{tabular}{llcccc}
\hline Dependent Variable & Independent Variables & Beta & $\mathrm{t}$ & $\mathrm{p}$ & $\mathrm{R}^{2}$ \\
\hline \multirow{4}{*}{ Forgiveness } & Tarit Anger & -.191 & -2.222 & $.027^{*}$ & \\
& Anger-In & -.155 & -2.443 & $.015^{*}$ & \\
& Anger-Out & -.090 & -1.104 & .271 & \\
& Anger Control & .231 & 3.682 & $.000^{*}$ & .423 \\
& Gratitude & .132 & 2.185 & $.030^{*}$ & \\
& Psychological Well-Being & .196 & 3.075 & $.002^{*}$ & \\
\hline
\end{tabular}

Model: $F=26.103 ; p=.000 ;{ }^{*} p<0.05$

The model formed according to the results of the regression analysis given in Table 3 is statistically significant $(F=26.103 ; p=.000<0.05)$. Considering the standardized regression coefficients $(\beta)$ in order to see the variables respectively predicting the level of forgiveness in a statistically significant way, trait anger and anger-in dimensions negatively predicted the level of forgiveness $(\beta=-.191 ; \beta=-.155 ; p<0.05)$, while anger control dimension, gratitude and psychological well-being variables predicted the level of forgiveness in a positively significant way $(\beta=.231 ; \beta=.132 ; \beta=.196 ; p<0.05)$. Trait anger, anger-in and anger control dimensions and gratitude and psychological well-being variables explained $42 \%$ of the change in forgiveness $\left(R^{2}=.423\right)$. While anger control dimension, which has the greatest regression coefficient, has the highest power to predict forgiveness $(\beta=.231)$, the smallest regression coefficient, gratitude has the lowest predictive power $(\beta=132)$. Anger-out sub-dimension was not a significant predictor of the level of forgiveness $(\beta=-.090 ; \beta=-.155 ; p>0.05)$.

\section{Result, Discussion and Suggestions}

In this study, the relationship of anger, gratitude and psychological well-being variables with forgiveness and their effects on forgiveness were examined in the light of national and international literature. According to the findings of the research related to the relationship between anger and forgiveness, it was found that there was 
a negatively significant relationship between trait anger and anger-in and forgiveness. While there was no significant relationship between anger-out and forgiveness, a positive relationship was found between anger control and forgiveness. Most crosssectional and longitudinal studies in the literature showed negative relationships between forgiveness and anger (Barber, Maltby \& Macaskill, 2005; Fincham \& Beach, 2002; VanOyen-Witvliet, Ludwig \& Vander-Laan, 2001). In various samples, those reported with higher anger levels got lower scores on forgiveness scales (Berry et al., 2005; Moore \& Dahlen, 2008; Rohde-Brown \& Rudestam, 2011; Seybold, Hill, Neumann \& Chi, 2001). Spielberger (1983) approached emotion of anger as state and trait, and while defined the state anger as the prevention or the severity of the emotion against injustice; trait anger explains as a concept that reflects how often state anger is experienced (Özer, 1994). Individuals with high trait anger levels experience state anger frequently and intensively (Deffenbacher, Oetting, Lynch \& Morris, 1996). Expectedly, these individuals are less likely to regret and learn lessons from the negative experiences in which anger is expressed, and interpersonal problems are more common (Dilekler, Törenli \& Selvi, 2014). Among individuals with low trait anger level, on the contrary, anger is expressed in a constructive way therefore interpersonal relations become more positive. According to the results obtained from the findings of the research, it can be said that as trait anger increases, forgiveness will be difficult. Therefore, reducing the level of anger and increasing anger control should be considered as a variable that can be functional in increasing forgiveness.

Similar to the findings of the research related to anger expression styles, Choi, Tae, Heo and Kim (2016) found a negative significant relationship between anger-in and forgiveness in their research on nurses, and it was reported that decreasing the anger level and increasing the level of forgiveness would enhance the quality of life among clinical nurses. If the person who keeps the anger in, namely suppresses the anger, can direct his/her attention to positive things, they can eventually transform it into more constructive behavior. As an inner process, in the core of forgiveness lies negative emotions to be transformed into positive emotions, the use of forgiveness interventions in the process is effective in reducing anger (Berry et al., 2005; McCullough et al., 2003; Zhang et al., 2019). However, for people whose anger is expressed, forgiveness may not be easy. Davies (2000) stated that when anger is suppressed internally, thoughts and moral judgments play roles, and when anger is suppressed externally, the consequences of this behavior play a role. When anger is not properly expressed, it goes up in time and causes to turn into feelings, thoughts and behaviors such as grudge, hate, hostility and revenge (Nakagawa et al., 2017). The results of studies of Vangelisti \& Young (2000) and Bugay \& Demir (2011) showed that the variables related to mistake - such as considering that the mistake was done deliberately, responsibility of the mistake, the results caused by the mistake, who have done the mistake- caused hostile feelings and reduced the forgiveness. Again, in the study of Yildı (2017) with adolescents who had 
delinquency problems, it was determined that the adolescents who were in the penal institution for the first time were more likely to forgive than those who were there more than once; the adolescents who had friends in prison had tendency of forgiveness in a distancing- getting away manner compared to those who did not have friends. Similarly to the finding that forgiveness will increase as the anger control skill of the individual increases, as a result of the studies of Kozan, Kesici and Baloğlu (2017), the university students whose anger control skill were low had also low level of forgiveness of self, others and situation. Positive and negative emotions play an important role in the process of forgiveness (Hodgson \& Wertheim, 2007). Despite the rational relationship between anger and forgiveness, researches examining the relationship between anger management and forgiveness are more limited to suggest that forgiveness interventions can effectively reduce anger (Goldman \& Wade, 2012; Welton, Hill \& Seybold, 2008). On the contrary, there are very few studies that support the idea of adding the forgiveness intervention to the intervention methods related to anger management will increase the effectiveness. One of them is Ballard's study (2011) on the anger management practice with 187 people in a polyclinic center who experience anger problems. In the study, the counselees were randomly assigned to the usual anger management program and the anger management program integrated with forgiveness and participated in 90-minute group therapy once a week during 12 weeks. Research results showed that the integrated program reduced state anger and it was effective in increasing anger control and forgiveness.

Another finding of the study is that there is a positive significant relationship between gratitude and psychological well-being and forgiveness. Gratitude and forgiveness are defined as the strengths of "heart", they are key factors in determining the level of happiness, which are 'emotional' and 'interpersonal' in nature and play an important role (Park \& Peterson, 2010; Safaria, 2014). As a result of the research of Satıc1, Uysal and Akın (2014) examining the mediating role of gratitude in the relationship of forgiveness and revenge, it was found that as forgiveness increased, feelings of revenge decreased and gratitude played an intermediary role in this increase. Accordingly, it can be said that gratitude contributes to the ability of forgiveness to transform negative emotions into positive emotions. There are studies reporting that gratitude is an important determinant of forgiveness (Breen et al., 2010; McCullough et al., 2002; Neto, 2007). On the other hand, there are opinions that both forgiveness and gratitude interventions can be beneficial to counselees as an intervention method, as well as emphasizing first gratitude then forgiveness can be more beneficial in the intervention (Toussaint \& Friedman, 2009). However, more clinical studies and researches are needed on these issues. Just like gratitude, psychological well-being also nurtures positive emotions in individuals and thus, they feel satisfaction and happiness in their lives (Wulandari \& Megawati, 2019). It can be said that individuals with high levels of psychological well-being are more forgiving than individuals with low levels. In a study of Asıc1 (2018) on university 
students, their level of forgiveness increased as the level of well-being, self-control, emotionality and sociality increased; well-being and self-control were found to be significant predictors of forgiveness. Many studies showing that there are significant relationships between forgiveness and psychological well-being of the individual can also be found in the literature (Alfonso \& Datu; 2014; Koç et al., 2016; Mugrage, 2014; Zümbül, 2018).

As a result, the common effect of anger, gratitude, and psychological well-being variables explained $42 \%$ of the variance related to the level of forgiveness of adults. It can be said that when individuals control anger, which is a natural emotion, when they thank and feel psychologically good, their tendency and actions about forgiveness will increase. Considering the feature of forgiveness transforming negative emotions into positive emotions, it can be said that including interventions related to forgiveness in guidance and psychological counseling services is important. In addition to the use of these interventions solely, it is thought that including them in current intervention and prevention services in an integrative way will increase forgiveness.

In this research, the relationships between anger, gratitude and psychological wellbeing and forgiveness presented at significant level. Considering the impact of this research on psychologists, psychological counselors and educators working in the field of mental health, further studies are needed to examine the determinants of forgiveness. The study has certain limitations. These can be counted as data collection with measurement tools based on self-report on a small sampling, following a relational method and not putting forward causality. It can be suggested that considering these limitations, researchers shall be recommended to conduct different research methods on larger sample groups for future researches. In the framework of multicultural psychological counseling services, conducting relational and experimental studies about forgiveness on different cultures and beliefs are among the suggestions. There has been a growing interest in interventions related to positive psychology in recent years. It is foreseen that especially the techniques and methods related to forgiveness and gratitude will have an important place in psychological counseling.

\section{Acknowledgement}

Since this study was conducted on the data collected before 2020, the ethical committee approval condition was not sought. However, the working stages comply with the principles set out in the Helsinki Declaration. 


\section{References}

Alfonso, J., \& Datu, D. (2014). Forgiveness, gratitude and subjective well-being among filipino adolescents. International Journal for the Advancement of Counseling, 36(3), 262-273. https:// doi.org/10.1007/s10447-013-9205-9

Ballard, M.S.. (2017). Integrating forgiveness therapy and the treatment of anger: A randomized controlled trial. (Doctoral Dissertation, University of Denver). https://digitalcommons.du.edu/ cgi/viewcontent.cgi?article $=2324 \&$ context $=$ etd

Barber, L., Maltby, J., \& Macaskill, A. (2005). Angry memories and thoughts of revenge: The relationship between forgiveness and anger rumination. Personality and Individual Difference, 39, 253-262. https://doi.org/10.1016/j.paid.2005.01.006

Berry, J.W., Worthington, E.L., O’Connor, L.E., Parrott, L., \& Wade, N.G. ( 2005). Forgivingness, vengeful rumination, and affective traits. Journal of Personality, 73, 183-225. https://doi. org/10.1111/j.1467-6494.2004.00308.x

Boleyn-Fitzgerald, P. (2002). What should forgiveness mean? The Journal of Values Inquiry, 36, 483-498.

Breen, W.E., Kashdan, T.B., Lenser, M.L., \& Fincham, F.D. (2010). Gratitude and forgiveness: Converge and divergence on self-report and informant ratings. Personality and Individual Differences, 49(8), 932-937. https://doi.org/10.1016/j.paid.2010.07.033

Bugay. A., Demir, A., \& Delevi. R. (2012). Assessment of the reliability and validity of the Turkish version of Heartland Forgiveness Scale. Psychological Reports, 111(2), 575-584. https://doi. org/10.2466/08.21.PR0.111.5.575584

Bugay, A., \& Demir, A. (2011). Hataya ilişkin özelliklerin başkalarını affetmeyi yordaması. Türk Psikolojik Danışma ve Rehberlik Dergisi, 4(35), 8-17.

Choi, J. H., Tae, Y. S., Heo, J. E., \& Kim, Y. S. (2016). The relationship among anger-in, forgiveness, and quality of life in clinical nurses, Journal of East-West Nursing Research, 22(1), 78-86. https://doi.org/10.14370/JEWNR.2016.22.1.78

Coyle, C.T., \& Enright, R.D. (1998). Forgiveness intervention with postabortion men. Journal of Counsulting and Clinical Psychology, 65(6), 1042-1046. https://doi.org/10.1037//0022006X.65.6.1042

Davies, W. (2000). Overcoming anger and irritability (2nd ed.). New York Universty Press.

Deffenbacher, J.L., Oetting, E.R., Lynch, R.S., \& Morris, C.D. (1996). The expression of anger and its consequences. Behaviour Research and Therapy, 34, 575-590. https://doi.org/10.1016/00057967(96)00018-6

Diener, E., Wirtz, D., Tov, W., Kim-Prieto, C., Choi, D., Oishi, S., \& Biswas-Diener, R. (2010). New wellbeing measures: Short scales to assess flourishing and positive and negative feelings. Social Indicators Research, 97, 143-156. https://doi.org/10.1007/s11205-009-9493-y

Dilekler, İ., Törenli, Z., \& Selvi, K.. (2014). Öfkeye farklı açılardan bakış: Öfkenin mekanizması, farklı psikopatolojilerde öfke ve terapistin öfkesi. Ayna Klinik Psikoloji Dergisi, 1(3), 44-59. https://doi.org/10.31682/ayna.470591

Enright, R. D., \& Fitzgibbons, R. P. (2015). Forgiveness therapy: An empirical guide for resolving anger and restoring hope. American Psychological Association. https://doi.org/10.1037/14526-000

Fincham, F.D., \& Beach, S.R.H. (2002). Forgiveness in marriage: Implications for psychological aggression and constructive communication. Personal Relationships, 9(3), 239-251. https://doi. org/10.1111/1475-6811.00016 
Fredrickson, B. L. (2004). Gratitude like other positive emotions, broadens and builds. In R. A. Emmons \& M. E. McCullough (Eds.), Series in affective science. The psychology of gratitude (pp.145-166). Oxford University Press. https://doi.org/10.1093/acprof:oso/9780195150100.003.0008

Gismero-Gonzales, E., Jodar, R., Martinez, M.P., Carrasco, M.J., Cagigal, V., \& Prieto-Ursua, M. (2020) Interpersonal offenses and psychological well-being: The mediating role of forgiveness, Journal of Happiness Studies, 21, 75-94. https://doi.org/10.1007/s10902-018-00070-x

Goldman, D.B., \& Wade, N.G. (2012). Comparison of forgiveness and anger-reduction group treatments: A randomized controlled trial, Psychotherapy Research, 22(5), 604-620. https://doi. org/10.1080/10503307.2012.692954

Güleç, C. (2016). Pozitif ruh să̆llğı.(3. Bask1). Arkadaş Yayınevi.

Hendricks, L. V., Bore, S., Aslinia, D., \& Morriss, G. (2013). The effects of anger on the brain and body. National Forum Journal of Counseling and Addiction, 2( 1), 1-11.

Hodgson, L. K., \& Wertheim, E. H. (2007). Does good emotion management aid forgiving? Multiple dimensions of empathy, emotion management and forgiveness of self and others. Journal of Social and Personal Relationships, 24(6), 931-949. https://doi.org/10.1177/0265407507084191

Kardaş, F., \& Yalçın, İ. (2018). Şükran: Ruh sağlı̆̆ı alanında güncel bir kavram. Psikiyatride Güncel Yaklaşımlar, 10(1), 1-18. https://doi.org/10.18863/pgy.334494

Kozan, H. İ. Ö., Kesici, Ş., \& Baloğlu, M. (2017). Affedicilik ve duyguları yönetme becerisi arasındaki çoklu ilişkinin incelenmesi. Değerler Eğitim Dergisi, 15(34), 193-215.

Koç, M., İskender, M., Çolak, T. S., \& Düşünceli, B. (2016). Investigation of the effect of intolerance of uncertainty and the effect of anger control on the relationship between forgiveness and psychological well-being through structural equation modelling. Sakarya University Journal of Education, 6 (3), 201-209. http://dx.doi.org/10.19126/suje.282951

Krause, N., \& Ellison, C. G. (2003). Forgiveness by God, forgiveness of others, and psychological well-being in late life. Journal for the Scientific Study of Religion, 42(1), 77-94. https://doi. org/10.1111/1468-5906.00162rre,

J.M., Serrano, J.P., Ros, L., Aguilar, M.J.,\& Navarro, B. (2008). Autobiographical memory, life revision and positive emotions in old age. In C. Vázquez \& G. Hervás (Eds.), Psicología Positiva Aplica$d a$ (pp.339-369). Descleé de Brouwer.

Lyubomirsky, S. (2008) The how of happiness: a scientific approach to getting life you want. Penguin Press.

Ma, C., Chen, M., \& Guo, N. ( 2019). The effect of interpersonal trust on minority high school students' psychological well-being the mediating roles of forgiveness and self-esteem. Advances in Social Science, Education and Humanities Research, 356, 525-529. https://doi.org/10.2991/ cesses-19.2019.119

Malakçıŏlu, C. (2018). Bitirilmemiş işler ile öfke, suçluluk, utanç ve affetme arasındaki ilişkilerin incelenmesi. (Doktora Tezi, Hacettepe Üniversitesi Eğitim Bilimleri Enstitüsü). https://tez.yok. gov.tr/UlusalTezMerkezi/

McCullough, M.E., Emmons, R.A., \& Tsang, J. (2002). The grateful disposition: A conceptual and empirical topography, Journal of Personality and Social Psychology, 82(1), 112-127. https:// doi.org/10.1037/0022-3514.82.1.112 
McCullough, E.M., Lindsey, M.R., Benjamin, A.T., \& Witvlient, C.O. (2005). Forgiveness. In Shane J. Lopez \& C.R. Snyder (Eds.), The Oxford Handbook of Positive Psychology (2nd ed.). Oxford University Press. https://doi.org/10.1093/oxfordhb/9780195187243.013.0040

Moore, M., \& Dalhen, E.R. (2008). Forgiveness and consideration of future consequences in aggressive driving. Accident Analysis and Prevention, 40, 1661-1666. https://doi.org/10.1016/j.aap.2008.05.007

Mugrage, M.S.(2014). The relationship between emotional intelligence and forgiveness. (Doctoral Theses Dissertations, The Chicago School of Professional Psychology). https://search.proquest. com/docview/1626038640?accountid=17170

Nakagawa, S., Takeuchi, H., Taki, Y., Nouchi, R., Sekiguchi, A., Kotozaki, Y., Miyauchi, C. M., Iizuka, K., Yokoyama, R., Shinada, T., Yamamoto, Y., Hanawa, S., Araki, T., Hashizume, H., Kunitoki, K., Sassa, Y., \& Kawashima, R. (2017). The anterior midcingulate cortex as a neural node underlying hostility in young adults. Brain Structure \& Function, 222(1), 61-70. https:// doi.org/10.1007/s00429-016-1200-6

Neto, F. (2007). Forgiveness, personality and gratitude. Personality and Individual Differences, 43(8), 2313-2323. https://doi.org/10.1016/j.paid.2007.07.010.

Nussbaum, M. (2016). Anger and forgiveness: resentment, generosity, justice. Oxford University Press.

Özer, A.K. (1994). Sürekli öfke ve öfke ifadesi tarzı ölçekleri ön çalışması. Türk Psikoloji Dergisi, 9 (31): 26-35.

Park, N., \& Peterson, C. (2010). Does it matter where we live? The urban psychology of character strengths. American Psychologist, 65(6), 535-547. https://doi.org/10.1037/a0019621

Rohde-Brown, J., \& Rudestam, K.E. (2011) The role of forgiveness in divorce adjustment and the impact of affect. Journal of Divorce \& Remarriage, 52(2), 109-124. https://doi.org/10.1080/10 502556.2011.546233

Ryff, C. D. (1989). Happiness is everyting, or is it? Explorations on the meaning of psychological well-being. Journal of Personality and Social Psychology, 57(6), 1069-1081. https://doi. org/10.1037/0022-3514.57.6.1069

Ryff, C. D., \& Singer, B. H. (1998). The contours of positive human health. Psychological Inquiry, 9, 1-28. https://doi.org/10.1207/s15327965pli0901_1.

Safaria, T. (2014). Forgiveness, gratitude and happiness among college students. International Journal of Public Health Science, 3(4), 241-245. https://doi.org/10.11591/ijphs.v3i4.4698

Satıc1, S. A., Uysal, R., \& Akın, A. (2014). Forgiveness and vengeance: The mediating role of gratitude. Psychological Reports, 114(1), 157-168. https://doi.org/10.2466/07.09.PR0.114k11w9

Seybold, K. S., Hill, P. C., Neumann, J. K., \& Chi, D. S. (2001). Physiological and psychological correlates of forgiveness. Journal of Psychology and Christianity, 20(3), 250-259.

Sharma, S., \& Das, I. (2017). Contribution of anger, gratitude and subjective well-being as predictors of forgiveness. Indian Journal of Positive Psychology, 8(3), 407-410.

Spielberger, C. D. (1983). State-Trait Anxiety Inventory for Adults (STAI-AD). APA PsycTests. https://doi.org/10.1037/t06496-000

Telef, B. B. (2013). Psikolojik iyi oluşölçeği(PIOO): Türkçeye uyarlama, geçerlik ve güvenirlik çalışması. Hacettepe Eğitim Fakültesi Dergisi, 28(3), 374-384. https://doi.org/10.17679/iuefd.16250801

Thompson, L. Y., Snyder, C. R., Hoffman, L., Michael, S. T., Rasmussen, H. N., \& Billings, L. S. (2005). Dispositional forgiveness of self, others, and situations. Journal of Personality, 2(73), 313-360. https://doi.org/10.1111/j.1467-6494.2005.00311.x 
Topbaşoğlu-Altan, T., \& Çivitçi, A. (2017). Öfke ve yaşam doyumu arasındaki ilişkide affetmenin düzenleyici rolü. Mehmet Akif Ersoy Üniversitesi Sosyal Bilimler Dergisi, 9(18), 308-327. https://doi.org/ 10.20875/makusobed.302756

Toussaint, L., \& Webb, J. R. (2005). Theoretical and empirical connections between forgiveness, mental health, and well-being. In E. L. Worthington, Jr. (Ed.), Handbook of forgiveness (pp. 349-362). Routledge.

Toussaint, L., \& Friedman, P. (2009). Forgiveness, gratitude, and well-being: The mediating role of affect and beliefs. Journal of Happiness Studies, 10, 635-654. https://doi.org/10.1007/s10902-008-9111-8

Uysal, R. \& Satic1, S.A. (2014). The mediating and moderating role of subjective happiness in the relationship between vengeance and forgiveness. Educational Sciences: Theory \& Practice, 14(6), 2097-2105. https://doi.org/10.12738/estp.2014.6.2207

VanOyen-Witvliet, C., Ludwig, T.E., \& Vander-Laan, K.L. (2001). Granting forgiveness or harboring grudges: Implications for emotion, Physiology, and Health. Psychological Science, 12(2), 117-123. https://doi.org/10.1111/1467-9280.00320

Vangelisti, A. L., \& Young, S. L. (2000). When words hurt: The perceived intentionality on interpersonal relationships. Journal of Social and Personal Relationships, 17, 393-425. https:// doi.org/10.1177/0265407500173005

Yıldız, M. (2017). Suça sürüklenen ergenlerde affetme üzerine bir inceleme. Toplum ve Bilim Dergisi, 11(22), 39-52. https://doi.org/10.15869/itobiad.33178

Wade, N.G., ,Hoyt, W.T., Kidwell, J.E.M., \& Worthington, E.L. (2014) Efficacy of psychotherapeutic interventions to promote forgiveness: A meta-analysis. Journal of Consulting and Clinical Psychology, 82(1), 154-170. https://doi.org/10.1037/a0035268

Watkins, P. C., Woodward, K., Stone, T., \& Kolts, R. L. (2003). Gratitude and happiness: Development of a measure of gratitude and relationships with subjective well-being. Social Behavior and Personality, 31(5), 431-452. https://doi.org/10.2224/sbp.2003.31.5.431

Welton, G. L., Hill, P. C., \& Seybold, K. S. (2008). Forgiveness in the trenches: Empathy, perspective taking, and anger. Journal of Psychology and Christianity, 27(2), 168-177.

Worthington, E. L., Witvliet, C., Lerner, A., \& Scherer, M. (2005). Forgiveness in health research and medical practice. Explore, 1, 169-176. https://doi.org/10.1016/j.explore.2005.02.012

Worthington, E.L., \& Scherer, M. (2004). Forgiveness is an emotion-focused coping strategy that can reduce health risks and promote health resilience: Theory, Review, and Hypotheses. Psychology And Health, 19(3), 385-405. https://doi.org/10.1080/0887044042000196674

Wu, Q., Chi, P., Lin, X. \& Du, H.(2018). Child maltreatment and adult depressive symptoms: Roles of self-compassion and gratitude. Child Abuse \& Neglect, 80, 62-69. https://doi.org/10.1016/j. chiabu.2018.03.013

Wulandari, I. \& Megawati, F.E. (2019). The role of forgiveness on psychological well-being in adolescents: A review. Advances in Social Science, Education and Humanities Research, 395, 99-103. https://doi.org/10.2991/assehr.k.200120.022

Zhang, D., Li, S., Shao, L., Hales, A. H., Williams, K. D., \& Teng, F. (2019). Ostracism increases automatic aggression: The role of anger and forgiveness. Frontiers in Psychology, 10, 2659. https://doi.org/10.3389/fpsyg.2019.02659

Zümbül, S. (2019). Öğretmen adaylarının psikolojikiyi oluş düzeylerindebilinçli farkındalık veaffetmenin yordayıc1 rolleri. Ege Eğitim Dergisi, 20(1), 20-36. https://doi.org/10.12984/egeefd.481963 